ECREG STUDIES

Vol. 13, No. 1, 2020 www.ers.edu.pl PDF OPEN ACCESS eISSN 2451-182X

Authors' contribution/

Wkład autorów:

A. Study design/ Zaplanowanie badań

B. Data collection/ Zebranie danych

C. Statistical analysis/ Analiza statystyczna

D. Data interpretation/ Interpretacja danych/

E. Manuscript preparation/ Przygotowanie tekstu

F. Literature search/ Opracowanie piśmiennictwa

G. Funds collection/ Pozyskanie funduszy

ORIGINAL ARTICLE

JEL code: JEL: H23, H61, H73

Submitted:

February 2020

Accepted:

March 2020

Tables: 4

Figures: 0

References: 16

\section{ECONOMIC AND REGIONAL STUDIES}

STUDIA EKONOMICZNE I REGIONALNE

ISSN 2083-3725

Volume 13, No. 1, 2020

\title{
GREEN TOURISM AS A FACTOR OF DEVELOPMENT OF UNITED TERRITORIAL COMMUNITIES IN UKRAINE
}

\section{TURYSTYKA EKOLOGICZNA CZYNNIKIEM ROZWOJU ZJEDNOCZONYCH WSPÓLNOT TERYTORIALNYCH NA UKRAINIE}

\author{
Oryslava Korkuna ${ }^{1(A, C, D, E)}$, Ivan Korkuna ${ }^{1(A, F)}$, Oksana Kulyk ${ }^{2(G)}$
}

${ }^{1}$ I. Boberskyi Lviv State University of Physical Culture, Hotel Restaurant Business Department, Ukraine

I. Boberskyi, Lwowski Państwowy Uniwersytet Kultury Fizycznej, Katedra Hotelarstwa i Gastronomii, Ukraina

${ }^{2}$ I. Boberskyi Lviv State University of Physical Culture, Tourism Faculty, Ukraine I. Boberskyi, Lwowski Państwowy Uniwersytet Kultury Fizycznej, Wydział Turystyki, Ukraina

Korkuna, O., Korkuna, I., Kulyk, O. (2020). Green tourism as a factor of development of United Territorial Communities in Ukraine/ Turystyka ekologiczna czynnikiem rozwoju zjednoczonych wspólnot terytorialnych na Ukrainie. Economic and Regional Studies, 13(1), p. 126-136. https://doi.org/10.2478/ers-2020-0009

Subject and purpose of work: Today, each united territorial community (UTC) has tourist potential, but not all can recognise, evaluate and use it. This paper deals with presenting contemporary issues and identifying prospects for green tourism development in united territorial communities.

Materials and methods: This paper includes general scientific and special methods of research, in particular, analysis and synthesis, systematisation and generalization, and the dialectical approach. A dialectical method of cognition is used to specify the features of rural green tourism organisation in the EU Member States.

Results: The internal potential and opportunities for its involvement in the development of green tourism in the UTC were determined. The foreign experience is analysed and the perspectives of use of their practice in the development of green tourism are considered. The complex of tasks of the UTC to ensure the development of rural green tourism in the UTC of Ukraine is highlighted. It is established that green tourism can be an additional factor in filling the revenue part of the UTC's budget and a factor in strengthening its capacity. A SWOT analysis of the development of green tourism in the UTCs of Ukraine was out. The main directions of development of green tourism were highlighted.

Conclusions: It was determined that green tourism could act as a catalyst for economic restructuring, provide demographic stability and solve the socio-economic problems arising nowadays during the formation and development of UTCs in Ukraine.

ORYGINALNY ARTYKUŁ NAUKOWY

Klasyfikacja JEL: JEL: H23, H61, H73

Zgłoszony:

luty 2020

Zaakceptowany:

marzec 2020

Tabele: 4

Rysunki: 0

Literatura: 16
Keywords: green tourism, budget, rural area, services, economic stability, territorial community

\section{Streszczenie}

Przedmiot i cel pracy: Obecnie każda zjednoczona wspólnota terytorialna (ZWT) dysponuje potencjałem turystycznym, który jednak nie wszyscy mogą dostrzec, ocenić i wykorzystać. Praca ma na celu przedstawienie współczesnych problemów i wskazanie perspektyw dla rozwoju turystyki ekologicznej w zjednoczonych wspólnotach terytorialnych.

Materiały i metody: Praca korzysta z ogólnych i specjalistycznych metod badawczych, w szczególności analizy i syntezy, systematyzacji i generalizacji oraz podejścia dialektycznego. Metoda dialektyczna poznania ma zastosowanie do określania cech organizacji agroturystyki ekologicznej w państwach członkowskich UE.

Wyniki: Określono wewnętrzny potencjał i możliwości jego wykorzystania w rozwoju turystyki ekologicznej w ZWT. Doświadczenia innych krajów poddano ocenie i rozważono perspektywy wykorzystania stosowanych przez nie praktyk w rozwoju turystyki ekologicznej. Podkreślono złożoność zadań ZWT

Address for correspondence/ Adres korespondencyjny: Dr Oryslava Korkuna (irima150@gmail.com), ORCID 0000-0002-8134-3771; Ivan Korkuna (korkuna@lbi.wubn.net), ORCID 0000-0002-8203-5412; Oksana Kulyk (grafskayaorislava@gmail.com), I. Boberskyi Lviv State University of Physical Culture, Tadeusha Kostyushka Street, 11, Lviv, Lviv Oblast, 79000 Ukraine.

Journal indexed in/ Czasopismo indeksowane w: AgEcon Search, AGRO, Arianta, Baidu Scholar, BazEkon, Cabell's Whitelist, CNKI Scholar, CNPIEC - cnpLINKer, EBSCO Discovery Service, EBSCO - CEEAS, EuroPub, Google Scholar, Index Copernicus, J-Gate, KESLI-NDSL, MyScienceWork, Naver Academic, Naviga (Softweco), POL-index, Polish Ministry of Science and Higher Education 2015-2018: 9 points; Primo Central (ExLibris), QOAM, ReadCube, Semantic Scholar, Summon (ProQuest), TDNet, WanFang Data, WorldCat (OCLC). Copyright: (c) Pope John Paul II State School of Higher Education in Biała Podlaska, Oryslava Korkuna, Ivan Korkuna, Oksana Kulyk. All articles are distributed under the terms of the Creative Commons Attribution-NonCommercial-ShareAlike 4.0 International (CC BY-NC-SA 4.0) License (http://creativecommons.org/ licenses/by-nc-sa/4.0/D, allowing third parties to copy and redistribute the material in any medium or format and to remix, transform, and build upon the material, provided the original work is properly cited and states its license. 
mających na celu rozwój agroturystyki ekologicznej w ZWT na Ukrainie. Stwierdzono, że turystyka ekologiczna może stanowić dodatkowy czynnik zwiększający przychody ZWT oraz poszerzający ich zdolności. Przeprowadzono analizę SWOT rozwoju turystyki ekologicznej w ZWT na Ukrainie. Wyróżniono główne kierunki rozwoju turystyki ekologicznej.

Wnioski: Stwierdzono, że turystyka ekologiczna może działać jak katalizator restrukturyzacji ekonomicznej, zapewniać stabilność demograficzną i oferować rozwiązanie problemów społeczno-gospodarczych pojawiających się współcześnie przy tworzeniu i rozwoju ZWT na Ukrainie.

Słowa kluczowe: turystyka ekologiczna, budżet, obszar wiejski, usługi, stabilność ekonomiczna, wspólnota terytorialna

\section{Introduction}

Today, community-based rural development is focused on building the foundations for sustainability, creating long-term capacity for communities to cope with future challenges and opportunities. It is a chain of action in which communities visualize, initiate and implement their own ideas for improving daily life. Changes are made by the communities themselves after they have been granted ownership, through effective use and control of local resources; they ensure that poverty is eliminated and not more comfortable living in poverty.

United territorial communities (UTCs) in the context of their development policies are selforganized people who share a common living space, united by desire, willingness and real action to improve their economic, social and environmental situation. With the further urbanization, the demand for green tourism will increase, as well as the need for rural estates and tourist attractions, which these services will be able to offer. Therefore, Ukraine has a rather powerful resource potential that is currently underutilized and, as a result, remains under-explored by tourists, especially in rural areas with rich cultural and historical heritage, significant nature conservation fund and food base. That is why, in the current conditions of formation of UTCs, the development of tourism influences on the stabilization of economic development of villages, which determines the importance of the topic being studied.

\section{Literature Review}

The issue of tourism development in the united territorial communities is completely new to national scientists, since the process of decentralization of power started not too long ago. These issues are now being considered more widely at the practical level, in particular by the participants of the Program «U-LEAD with Europe», as this program is the donor for the financing of the majority of projects in UTCs of Ukraine. The majority of Ukrainian scientists consider green tourism issues in rural areas, which then become the basis for tourism development in the UTC. In particular, A. Kravchuk and N. Popadynets claim that rural green tourism should be considered as a socio-cultural activity and as an industry that produces services necessary to meet needs that may arise during the travel (Kravchuk, 2014; Popadynets, 2018). G. Cherniava in her research gives definition

\section{Wstęp}

Obecnie rozwój obszarów wiejskich w oparciu o społeczności koncentruje się na budowaniu podstaw zrównoważonego rozwoju, tworzeniu długoterminowej zdolności społeczności do radzenia sobie z przyszłymi wyzwaniami i możliwościami. Jest to łańcuch działań, w ramach którego społeczności obrazują, inicjują i wprowadzają w życie własne pomysły na rzecz poprawy jakości codziennego życia. Zmiany dokonują się za sprawą samych społeczności po uzyskaniu przez nie własności, poprzez efektywne wykorzystanie i kontrolowanie miejscowych zasobów, zapewniając wyeliminowanie problemu ubóstwa i aktywizację społeczeństwa.

Zjednoczone wspólnoty terytorialne (ZWT) w kontekście ich strategii rozwoju składają się z samoorganizujących się osób, które zamieszkują na tym samym terytorium, zjednoczone chęcią działania na rzecz poprawy swojej sytuacji gospodarczej, społecznej i środowiskowej, W miarę postępującej urbanizacji zapotrzebowanie na turystykę ekologiczną będzie się zwiększać, podobnie jak potrzeba tworzenia obiektów agroturystycznych i atrakcji turystycznych, które będą zapewniane dzięki tego rodzaju usługom. Ukraina dysponuje silnym potencjałem zasobów, które obecnie nie są w pełni wykorzystywane, $\mathrm{w}$ wyniku czego pozostaje on nieznany dla turystów, w szczególności na obszarach wiejskich o bogatym dziedzictwie historycznym i kulturowym, znacznych środkach przeznaczanych na ochronę przyrody i bazie gastronomicznej. Dlatego w obecnych warunkach tworzenia ZWT rozwój turystyki wpływa na stabilizację rozwoju gospodarczego wsi, co świadczy o znaczeniu omawianego tematu.

\section{Przegląd literatury}

Kwestia rozwoju turystyki w zjednoczonych wspólnotach terytorialnych jest całkowicie nowa dla naukowców w kraju, ponieważ proces decentralizacji władzy rozpoczął się względnie niedawno. Kwestie te są obecnie rozpatrywane z szerszej perspektywy w ujęciu praktycznym, w szczególności przez uczestników programu „U-Lead z Europą”, który jest źródłem finansowania większości projektów w ZWT na Ukrainie. Wielu ukraińskich naukowców zajmuje się kwestiami agroturystyki ekologicznej, które następnie stanowią podstawę rozwoju turystyki w ZWT. W szczególności A. Kravchuk i N. Popadynets twierdzą, że agroturystyka ekologiczna powinna być rozpatrywana z perspektywy aktywności społeczno-kulturowej oraz jako branża, która zapewnia usługi konieczne do spełniania potrzeb wynikających z podróży (Kravchuk, 2014; Popadynets, 2018). G. Cherniava w swojej 
that "rural tourist product (complex of rural green tourism) is a set of lodging, catering, excursions and entertainment services provided by the homeowner" (Cherniava, 2012). L. Shulgin, A. Zinchenko and N. Krakhmaliov suggest to consider tourism service as a generalized concept of the created atmosphere, that is, the atmosphere creates an unforgettable positive impression of a tourist trip (Shulgin et al., 2014). O. Korchynska considers rural green tourism as a type of entrepreneurial activity "in providing recreation services in rural areas using private property of households and local natural and cultural resources" (Korchynska, 2015). N. Kudla claims that rural tourism is "a recreational type of tourism occurring in rural estates where the owner provides accommodation and catering services; the main purpose of this type of tourism is passive rest and study of peasants' life" (Kudla, 2015). Yu. Zinko, P. Gorishevsky, V. Vasilyev, S. Blagodyr, M. Ivanik offer the following definition: "rural tourism is a recreation type of tourism concentrated in rural areas and envisages the development of tourist infrastructure in the countryside to serve tourists". They define it as "a national brand of rural tourism, used to promote rural tourism services and products" (Zinko et al., 2011).

In our view, rural green tourism should be seen not simply as a brand, but an environmental component of the tourism service must be present in this type of activity. Thus, we believe that green and rural tourism is a business activity in the field of tourist services, which includes at least providing a place to stay of tourists in the bosom of nature (in the forest, in the mountains, in the countryside, etc.). The difference between rural and green tourism is that green tourism is not tied to staying of a tourist in the village. A tourist can live in the woods, in the dugout or in a tent. Common features are the ability to provide services related to such accommodation and recreation: in the green - picking berries, mushrooms, etc.; in the rural - studying the way of life, work on the land plot, etc. (but for leisure purposes, because tourism is first and foremost a rest).

The purpose of the article is to define the conditions and study the processes of green tourism development in the conditions of formation of united territorial communities in Ukraine.

\section{Methodology}

To achieve this, the scientific literature and documents on the stages of tourism development in Ukraine, in particular in the UTC, were analyzed. General scientific and special methods of research, in particular, analysis and synthesis, systematization and generalization, dialectical approach, were used in the study. A dialectical method of cognition is conducted to specify the features of rural green tourism organization in the EU Member States. pracy podaje następującą definicję: „,wiejski produkt turystyczny (kompleks agroturystyki ekologicznej) jest zbiorem usług zakwaterowania, wyżywienia, usług wycieczkowych i rozrywkowych zapewnianych przez właściciela obiektu" (Cherniava, 2012). L. Shulgin, A. Zinchenko i N. Krakhmaliov proponują traktowanie usługi turystycznej jako uogólnionej koncepcji tworzonej atmosfery, czyli atmosfery, która tworzy niezapomniane pozytywne wrażenia z podróży turystycznej (Shulgin i wsp., 2014). O. Korchynska rozumie agroturystykę ekologiczną jako rodzaj działalności gospodarczej „polegającej na świadczeniu usług rekreacyjnych na obszarach wiejskich z wykorzystaniem własności prywatnej gospodarstw domowych i lokalnych zasobów naturalnych i kulturowych" (Korchynska, 2015). N. Kudla twierdzi, że agroturystyka jest „rodzajem turystyki rekreacyjnej na obszarach wiejskich, w ramach której właściciel zapewnia zakwaterowanie i wyżywienie; głównym celem tego rodzaju turystyki jest bierny wypoczynek i poznawanie życia na wsi" (Kudla, 2015). Yu. Zinko, P. Gorishevsky, V. Vasilyev, S. Blagodyr, M. Ivanik proponują następującą definicję: „agroturystyka jest rodzajem turystyki rekreacyjnej skupionej na obszarach wiejskich, która przewiduje rozwój infrastruktury turystycznej na wsi z myślą o turystach”. Określają ją jako „krajową markę agroturystyki, za pomocą której prowadzona jest promocja usług i produktów agroturystycznych" (Zinko i wsp., 2011).

W opinii autorów agroturystyka ekologiczna powinna być rozumiana nie tylko jako marka, ale musi obejmować element środowiskowy. Dlatego według autorów turystyka ekologiczna i agroturystyka stanowią działalność gospodarczą w obszarze usług turystycznych, która obejmuje co najmniej zapewnienie turystom zakwaterowania na łonie natury (w otoczeniu lasu, gór, na wsi itd.). Różnica między agroturystyką a turystyką ekologiczną wyraża się w tym, że ta druga nie jest związana z pozostawaniem turysty na wsi. Może on mieszkać w lesie, w ziemiance lub namiocie. Cechy wspólne obejmują zdolność do świadczenia usług związanych z zakwaterowaniem i rekreacją - na łonie natury może to być zbieranie jagód, grzybów itp., a na wsi - poznawanie życia na wsi, praca na działce itd.) (w celach rekreacyjnych, ponieważ turystyka ma przede wszystkim funkcję wypoczynkową).

Celem niniejszego artykułu jest określenie warunków i zbadanie procesów rozwoju turystyki ekologicznej w warunkach tworzenia się zjednoczonych wspólnot terytorialnych na Ukrainie.

\section{Metodologia}

Aby zrealizować cel artykułu, dokonano analizy literatury naukowej i dokumentów dotyczących etapów rozwoju turystyki na Ukrainie, w szczególności w ZWT. Praca powstała dzięki zastosowaniu ogólnych i specjalistycznych metod badawczych, w szczególności analizy i syntezy, systematyzacji i generalizacji oraz podejścia dialektycznego. Metoda dialektyczna poznania służy do określania cech organizacji agroturystyki ekologicznej w państwach członkowskich UE. 


\section{Results and Discussions}

Today, in many regions of Ukraine, tourism is the mechanism that creates investment and development processes in this territory. This is one of the fastest ways to get money back in business. And yet, it is a phenomenal sphere, since it brings together more than 50 related industries. It attracts everyone from farmers and industrialists to those who take out the garbage. It is a cluster that is an indicator of the development of the local community, starting from the roads and ending with health care.

The European integration vector chosen by Ukraine needs to form the basis of a structural policy of the development of the UTC. However, it should follow the prescriptions of its own approach, taking into account historical experience and current practice. Fundamental changes in the economic mechanism of rural development were laid in 1985 through proposals to expand the rights of Ukrainian enterprises through independent organization of production, sale of products, development of the social sphere of the village. The declared restructuring of public administration was aimed at solving promising socio-economic and scientific-technical problems, the search for the most effective forms of integration of science and production. Questions were raised about improving management, eliminating unnecessary links, simplifying the structure of the management apparatus, increasing its efficiency, which remained unrealized (Rossokha, \& Plotnikova, 2018).

Such a course in Ukraine forces to take into account the experience of tourism, especially rural green tourism.

The massive development of rural green tourism in the world began in the second half of the twentieth century, when the concept of "Bed \& Breakfast” emerged in the United Kingdom and the United States. It implies a temporary stay of about 7 days in empty rooms of houses, regardless of their location. At the beginning of the XXI century the rural tourism industry is recognized by the experts of the World Tourism Organization as a significant, most dynamically growing sector of the world tourism industry. The volume of provision of rural tourism services in post-industrial countries is now almost 2-4 times higher than the growth of the hotel base and resort service in these countries (All about tourism, 2015).

It should be noted that today all the national rural tourism organizations in Europe have joined EuroGites. The main goals of this organization are to promote the development of rural green tourism and the targeted investment of rural tourism development projects (EuroGites, 2019). The principles of this organization today should be used in the newly created UTCs in Ukraine. After all, tourist clusters are important tools for tourism development at the regional level, and the newly created UTCs become the kind of centers where tourist products are born, which, after successful implementation, bring profits to the communities.

\section{Wyniki i dyskusja}

W wielu regionach Ukrainy turystyka jest dziś mechanizmem, który napędza procesy inwestycyjne i rozwojowe na danym obszarze. Jest to jeden z najszybszych sposobów na zasilenie działalności gospodarczej Jest to również niezwykły sektor, który zrzesza ponad 50 powiązanych branż. Działają w nim wszyscy, począwszy od rolników i przemysłowców, po osoby zajmujące się wywozem odpadów. Klaster ten stanowi wskaźnik rozwoju społeczności lokalnej, począwszy od dróg, a skończywszy na opiece zdrowotnej.

Kierunek integracji europejskiej obrany przez Ukrainę powinien stworzyć podstawy polityki strukturalnej rozwoju ZWT. Powinien on jednak przestrzegać własnych zasad, biorąc pod uwagę doświadczenie historyczne i bieżącą praktykę. Podstawowe zmiany w mechanizmie gospodarczym rozwoju obszarów wiejskich zostały wprowadzone w 1985 r. w formie propozycji zwiększenia uprawień ukraińskich przedsiębiorstw poprzez niezależną organizację produkcji, sprzedaży produktów i rozwój społeczny wsi. Deklarowana restrukturyzacja administracji publicznej miała na celu rozwiązanie problemów społeczno gospodarczych i naukowo-technicznych, poszukiwanie najskuteczniejszych form połączenia sfery nauki i produkcji. Poruszono kwestie poprawy zarządzania, eliminacji zbędnych pośredników, uproszczenia struktury zarządzania i zwiększenia jego skuteczności, jednak nie udało się ich zrealizować (Rossokha i Plotnikova, 2018).

Sytuacja na Ukrainie wymusza wzięcie pod uwagę doświadczeń branży turystycznej, w szczególności agroturystyki ekologicznej.

Intensywny rozwój agroturystyki ekologicznej na świecie rozpoczął się w drugiej połowie XX wieku, kiedy w Wielkiej Brytanii i Stanach Zjednoczonych powstało pojęcie „noclegu ze śniadaniem” (Bed \& Breakfast). Był to najczęściej około siedmiodniowy pobyt w wolnych pokojach domów prywatnych, niezależnie od ich lokalizacji. Na początku XXI wieku branża agroturystyczna została uznana przez ekspertów Światowej Organizacji Turystycznej za ważny, dynamicznie rozwijający się sektor światowego przemysłu turystycznego. Wolumen usług agroturystycznych w krajach poprzemysłowych jest obecnie 2-4 razy wyższy niż wzrost bazy hotelowej i usług letniskowych w tych krajach (All about tourism, 2015).

Należy zaznaczyć, że wszystkie krajowe organizacje agroturystyczne w Europie przyłączyły się do Europejskiej Federacji Turystyki Wiejskiej (EuroGites). Do głównych celów tej organizacji należy promowanie rozwoju agroturystyki ekologicznej i ukierunkowane inwestycje w projekty rozwoju agroturystyki (EuroGites, 2019). Zasady organizacji powinny teraz znaleźć zastosowanie $\mathrm{w}$ nowo tworzonych ukraińskich ZWT. Klastry turystyczne są wszak ważnymi narzędziami rozwoju turystyki na szczeblu regionalnym, a nowo tworzone ZWT stają się ośrodkami powstawania produktów turystycznych, które po ich pomyślnym wprowadzeniu przynoszą zyski lokalnym społecznościom.

Ponieważ ekoturystyka jest podstawą rozwoju turystyki w ZWT, bazując na doświadczeniach zagra- 
As green tourism is the foundation of tourism development in the UTC, relying on foreign experience, we can distinguish several basic features of some EU Member States in the organization of green tourism (Table 1).

Table 1. Characteristics of the organization of rural green tourism in the EU Member States

Tabela 1. Cechy organizacji agroturystyki ekologicznej w państwach członkowskich UE

\begin{tabular}{|c|c|}
\hline Countries/ Kraje & Characteristics/ Cechy \\
\hline Italy/ Włochy & $\begin{array}{l}\text { agrotourism business closely linked to the resort, international specialization is } \\
\text { astronomical and tasting tourism/ } \\
\text { działalność agroturystyczna ściśle związana z miejscowością wypoczynkową, } \\
\text { międzynarodowa specjalizacja w turystyce astronomicznej i degustacyjnej }\end{array}$ \\
\hline Austria/ Austria & $\begin{array}{l}\text { involving guests in gathering herbs, preparing dairy products, pasturing livestock, } \\
\text { active mountain and ecotourism/ } \\
\text { zaangażowanie gości w zbieranie ziół, przygotowanie nabiału, wypasanie zwierząt } \\
\text { gospodarskich, turystykę aktywną i ekoturystykę }\end{array}$ \\
\hline Finland/ Finlandia & $\begin{array}{l}\text { hostless lodges located on the banks of protected lakes and rivers/ } \\
\text { domki bez właścicieli położone na brzegach objętych ochroną jezior i rzek }\end{array}$ \\
\hline Romania/ Rumunia & $\begin{array}{l}\text { operates the National Association of Rural and Cultural Tourism, specializing in } \\
\text { ethnographic and gastronomic tourism/ } \\
\text { działa tu Krajowe Stowarzyszenie Agroturystyki i Turystyki Kulturowej, specjalizujące } \\
\text { się w turystyce etnograficznej i gastronomicznej }\end{array}$ \\
\hline Hungary/ Węgry & $\begin{array}{l}\text { tax incentives, international specialization is equestrian tourism/ } \\
\text { zachęty podatkowe, międzynarodowa specjalizacja w turystyce konnej }\end{array}$ \\
\hline Poland/ Polska & $\begin{array}{l}\text { lack of close connection with the traditions of the country - only accommodation and } \\
\text { meals/ } \\
\text { brak ścisłego powiązania z tradycją kraju - tylko zakwaterowanie i wyżywienie }\end{array}$ \\
\hline France/ Francja & $\begin{array}{l}\text { seaside farms, horse farms, wine farms, ski chalets, agro-cottages, castles, fishing } \\
\text { houses/ } \\
\text { gospodarstwa nad morzem, stadniny koni, gospodarstwa winiarskie, chaty narciarskie, } \\
\text { domki agroturystyczne, zamki, domki rybackie }\end{array}$ \\
\hline Spain/ Hiszpania & $\begin{array}{l}\text { rural hotels opened in the Canary and Balearic Islands, as well as in converted } \\
\text { monasteries and historic castles/ } \\
\text { hotele wiejskie na Wyspach Kanaryjskich i Balearach, a także w dawnych klasztorach i } \\
\text { zabytkowych zamkach }\end{array}$ \\
\hline Denmark/ Dania & $\begin{array}{l}\text { National Association of Agrotourism, specializing in cycling tourism/ } \\
\text { Krajowe Stowarzyszenie Agroturystyki, specjalizujące się w turystyce rowerowej }\end{array}$ \\
\hline Germany/ Niemcy & $\begin{array}{l}\text { most tourists come to participate in international fairs and trade shows/ } \\
\text { Większość turystów przyjeżdża w celu udziału w międzynarodowych targach i } \\
\text { wystawach handlowych }\end{array}$ \\
\hline United Kingdom/ Wielka Brytania & $\begin{array}{l}\text { affordable prices, special discounts for children, print advertising catalogs/ } \\
\text { przystępne ceny, specjalne zniżki dla dzieci, drukowane katalogi reklamowe }\end{array}$ \\
\hline
\end{tabular}

Source: All about tourism, 2015.

Źródło: All about tourism, 2015.

Thus, France and Spain hold the first place among the countries in the development of rural green tourism (by volume), in these countries tourism has developed into a highly profitable industry at the level of international specialization. In France, in most cases, the owners of the estate are urban residents or travel companies. There are about 5,000 rural hotels in Spain, 750 of which are in the category (1-4 tulips). Some of them are in ancient castles or monasteries. It is known that more than $56 \%$ of the population in the 27 Member States of the European Union (EU) reside in rural areas, covering 91\% of the entire EU territory. Among the main reasons for the high popularity and spread of rural green tourism in Europe are the following: a decrease in the share of the agricultural sector in the national economy (today the figure in the EU is $5 \%$, while in Ukraine the share of agricultural production in GDP is increasing and it is $10.43 \%$ ); increasing the level nicznych można wyróżnić podstawowe cechy organizacji ekoturystyki w niektórych państwach członkowskich UE (Tabela 1). 
of urbanization of the population; environmental degradation; degradation of food quality, etc. (Ivanyshyn and Dudzyak, 2019).

Investments in tourism can be both private and public. But they must reasonably be combined. For example, in the European Union, there are public development tools for local communities encouraging private investment. The role of the public sector is to prepare a local development strategy. And part of it should be the development of tourism and the preparation of the field of action for the private investor. The task of the state is to create conditions that would be attractive to the private sector (EuroGites, 2019).

In Ukraine, today there is also a certain basis for facilitating the formation and development of business in the UTC. Today we have a system of ecological certification and voluntary categorization "Green farmstead", developed by the All-Ukrainian Union for the promotion of rural green tourism. The certification scheme is based on the principles of reducing the adverse impact of agrotourism facility on the environment, support for folk traditions and crafts, support the local economy, the development of environmentally friendly types of entertainment and recreation (Ukrainian hospitable estates, 2019).

Rural green tourism is a new concept for the UTC of Ukraine, although it is developing quite actively. Today, in Ukraine the tourism industry is only the fifth largest component of the budget revenues and its share should increase significantly given such objective prerequisites as favorable geopolitical location of Ukraine in the center of Europe, the presence of significant tourist and recreational potential, favorable climate, rich flora and fauna, numerous world-class cultural and historical sites.

According to survey, from $100 \%$ of tourists taking advantage of rural tourism trips, for $35.2 \%$ it is "escape" from the busy rhythm of urban life, the opportunity to plunge into a leisurely rural life, relax with well-deserved "idleness", for $20.2 \%$ it is an opportunity to combine holidays with active amateur trips (hiking in the mountains or road to get acquainted with its historical and cultural heritage), $17.3 \%$ admitted that their trip prompted the desire for recreation in nature and communication with the world of the living, for $10.4 \%$ the purpose is family recreation (more attention to family and children), for $5.0 \%$ the purpose is sports tourism and use this cheaper lodging base, $11.9 \%$ has other purposes (Ukrainian hospitable estates, 2019). To assess the state of development of rural green tourism in Ukraine, we use the data in Table 2.

An analysis of the performance of rural green tourism estates in the regions of Ukraine revealed that this type of activity is uneven. The highest concentration of rural tourism establishments is in the Ivano-Frankivsk Oblast. It is known that the largest number of dwellings is in Verkhovyna, Kosiv districts and Yaremche town of Ivano-Frankivsk Oblast. Grouping by the number of estates has been done. The first group (high development) is the IvanoFrankivsk Oblast, which has the largest number of cja środowiska, pogorszenie się jakości żywności itd. (Ivanyshyn i Dudzyak, 2019).

Inwestycje w turystykę mogą być prywatne i publiczne. Ważne jest jednak ich odpowiednie połączenie. Na przykład w Unii Europejskiej działają publiczne narzędzia rozwoju dla społeczności lokalnych, które napędzają inwestycje prywatne. Rolą sektora publicznego jest przygotowanie lokalnej strategii rozwoju. Jej elementem powinien być rozwój turystyki i przygotowanie pola działania dla inwestora prywatnego. Zadaniem państwa jest stworzenie warunków, które byłyby atrakcyjne dla inwestora prywatnego (EuroGites, 2019).

Na Ukrainie obecnie są również pewne podstawy wspierania tworzenia i rozwoju działalności w ZWT. Działa system certyfikacji ekologicznej i dobrowolnej kategoryzacji „Zielone gospodarstwo” opracowany przez Ogólnoukraińską Unię Promocji Agroturystyki Ekologicznej. System certyfikacji opiera się na ograniczaniu negatywnego wpływu obiektu agroturystycznego na środowisko, wspieraniu tradycji i rzemiosła ludowego, wspieraniu lokalnej gospodarki, rozwoju przyjaznych dla środowiska form rozrywki i rekreacji (Ukrainian hospitable estates/ Obiekty hotelarskie na Ukrainie, 2019).

Agroturystyka ekologiczna jest nowym pojęciem dla ZWT na Ukrainie, chociaż rozwija się ona dość intensywnie. Obecnie na Ukrainie przemysł turystyczny jest zaledwie piątym z kolei największym składnikiem dochodów budżetowych, a jego udział powinien się znacznie zwiększyć, biorąc pod uwagę takie obiektywne warunki, jak lokalizacja geopolityczna Ukrainy w centrum Europy, obecność znaczącego potencjału turystycznego i rekreacyjnego, sprzyjający klimat, bogata flora i fana oraz liczne obiekty kulturowe i historyczne światowej klasy.

Według badania spośród wszystkich turystów korzystających z agroturystyki dla 35,2\% jest to odskocznia od intensywnego rytmu życia w mieście, możliwość zanurzenia się w sprzyjającym odpoczynkowi życiu wiejskim albo oddania się zasłużonej bezczynności. Dla $20,2 \%$ to szansa na połączenie wakacji z aktywnością (chodzenie po górach lub ścieżkach $\mathrm{w}$ celu zapoznania się z lokalnym dziedzictwem historycznym i kulturowym). Z kolei $17,3 \%$ przyznało, że ich podróż wzbudziła w nich pragnienie rekreacji na łonie natury i komunikacji ze światem przyrody, dla 10,4\% celem jest rekreacja rodzinna (większa uwaga poświęcona rodzinie i dzieciom), dla 5,0\% celem jest turystyka sportowa i korzystanie z tańszej baszy noclegowej, a 11,9\% wskazało na inne cele (Ukrainian hospitable estates, 2019). Do oceny stanu rozwoju agroturystyki ekologicznej na Ukrainie wykorzystano dane z Tabeli 2.

Analiza wyników obiektów agroturystyki ekologicznej w regionach Ukrainy wykazała, że tego rodzaju działalność charakteryzuje się nierównomiernym rozkładem. Największe skupienie obiektów agroturystycznych występuje w obwodzie iwanofrankiwskim. Wiadomo, że w tym obwodzie największa liczba obiektów znajduje się w rejonach wierchowińskim i kosowskim oraz mieście Jaremcze. Dokonano grupowania według liczby obiektów. Do pierwszej grupy (o wyso- 
Table 2. Analysis of quantitative indicators of rural green tourism establishments in the regions of Ukraine for 2017

Tabela 2. Analiza wskaźników ilościowych obiektów agroturystyki ekologicznej w regionach Ukrainy w 2017 r.

\begin{tabular}{|c|c|c|c|c|}
\hline Oblast/ Obwód & $\begin{array}{c}\text { Number of } \\
\text { estates, units/ } \\
\text { Liczba obiektów, } \\
\text { jednostek }\end{array}$ & $\begin{array}{c}\text { Share in total,\%/ } \\
\text { Udział } \\
\text { w wartości } \\
\text { ogólnej, \% }\end{array}$ & \begin{tabular}{|c|} 
Number of people \\
accommodated/ \\
Liczba osób, \\
które skorzystały \\
z noclegu \\
\end{tabular} & $\begin{array}{c}\text { Share in total,\%/ } \\
\text { Udział } \\
\text { w wartości } \\
\text { ogólnej, \% }\end{array}$ \\
\hline Vinnytsia Oblast/ Obwód winnicki & 1 & 0.26 & 35 & 0.04 \\
\hline Volyn Oblast/ Obwód wołyński & 2 & 0.33 & 2517 & 3.15 \\
\hline $\begin{array}{l}\text { Dnipropetrovsk Oblast/ Obwód } \\
\text { dniepropietrowski }\end{array}$ & 1 & 0.27 & 46 & 0.06 \\
\hline Zakarpattia Oblast/ Obwód zakarpacki & 4 & 1.07 & 271 & 0.34 \\
\hline $\begin{array}{l}\text { Ivano-Frankivsk Oblast/ Obwód } \\
\text { iwanofrankiwski }\end{array}$ & 305 & 81.33 & 55797 & 69.84 \\
\hline Kirovohrad Oblast/ Obwód kirowohradzki & 2 & 0.53 & 1590 & 1.99 \\
\hline Lviv Oblast/ Obwód lwowski & 16 & 4.27 & 2003 & 2.51 \\
\hline Mykolaiv Oblast/ Obwód mikołajowski & 2 & 0.53 & 765 & 0.96 \\
\hline Odessa Oblast/ Obwód odeski & 3 & 0.8 & 1606 & 2.01 \\
\hline Poltava Oblast/ Obwód połtawski & 1 & 0,27 & 50 & 0,06 \\
\hline Ternopil Oblast/ Obwód tarnopolski & 6 & 1.6 & 2609 & 3.27 \\
\hline Kherson Oblast/ Obwód chersoński & 1 & 0.27 & 232 & 0.29 \\
\hline Khmelnytskyi Oblast/ Obwód chmielnicki & 5 & 1.33 & 4114 & 5.1 \\
\hline Cherkasy Oblast/ Obwód czerkaski & 6 & $1, .6$ & 303 & 0.28 \\
\hline Chernivtsi Oblast/ Obwód czerniowiecki & 17 & 4.53 & 7034 & 8.8 \\
\hline Chernihiv Oblast/ Obwód czernihowski & 3 & 0.8 & 919 & 1.15 \\
\hline Total in Ukraine/ Ukraina ogółem & 375 & 100 & 79891 & 100 \\
\hline
\end{tabular}

Source: Compiled by the authors based on State Statistics Service of Ukraine, 2019.

Źródło: Sporządzone przez autorów na podstawie danych Państwowej Służby Statystycznej Ukrainy, 2019.

such establishments, whose share is $81.33 \%$ of the total in Ukraine. Accordingly, this area accounts for the largest flows of rural tourists. Therefore, based on the conducted analysis, newly established UTCs in those areas that have real potential in the development of green tourism can form this kind of activity as a basis for the development of their community. The priority of rural green tourism development in the UTC of Ukraine is determined by the urgent need to resolve the socio-economic problems of modern villages.

The issue of promoting the idea of green tourism as a whole is especially important now in the UTC. The purpose of developing this large-scale program should be raising public awareness and creating a positive attitude towards this type of recreation. First of all, marketing communications such as PR articles, interviews, press conferences, workshops, briefings, trusted and positive television programs should be involved.

The positive impact of tourism on addressing the socio-economic problems of the UTC is expanding the employment of rural population and giving farmers extra income, extending the employment opportunities of the farmer not only in the production sector but also in the service sector. Understanding of rural green tourism is being formed as a specific form of recreation in the countryside with a wide opportunity to use the natural, material and cultural potential of the region.

In order to ensure the priority of tourism development in the most UTCs of Ukraine and bring it closer to EU standards, there is an urgent need to adopt the Law of Ukraine "On Rural Green Tourism". The Law would become the basis for regional kim wskaźniku rozwoju) należy obwód iwanofrankiwski, w którym odnotowano największa liczbe takich obiektów, stanowiących 81,33\% wszystkich tego rodzaju obiektów na Ukrainie. Obszar ten odpowiada również za największy przepływ turystów na obszarach wiejskich. Dlatego na podstawie przeprowadzonej analizy nowo utworzone ZWT na tych obszarach mających prawdziwy potencjał rozwoju ekoturystyki mogą stworzyć ze swojej działalności podstawę rozwoju lokalnych społeczności. Priorytet dla rozwoju agroturystyki ekologicznej w ZWT na Ukrainie określa pilna potrzeba rozwiązania problemów społecznogospodarczych współczesnych wsi.

Kwestia wspierania idei ekoturystyki jako całości jest obecnie szczególnie ważna w ZWT. Celem przygotowania programu na dużą skalę powinno być uświadamianie opinii publicznej i tworzenie pozytywnego podejścia do tego rodzaju rekreacji. Po pierwsze, należy zastosować środki marketingowe, takie jak artykuły promocyjne, wywiady, konferencje prasowe, warsztaty, spotkania informacyjne, oraz cieszące się zaufaniem programy telewizyjne tworzące pozytywny wizerunek ekoturystyki.

Pozytywny wpływ turystyki na rozwiązywanie problemów społeczno-ekonomicznych ZWT przyczynia się do zwiększenia zatrudnienia ludności wiejskiej i stanowi dodatkowe źródło dochodów dla rolników, dając im możliwość pracy nie tylko w sektorze produkcji, ale także w sektorze usługowym. Rozumienie agroturystyki ekologicznej stanowi szczególną formę rekreacji na terenach wiejskich dzięki różnorodnym możliwościom wykorzystania potencjału naturalnego, materialnego i kulturowego regionu.

Aby zapewnić realizację priorytetu rozwoju turystyki w większości ZWT na Ukrainie i zbliżyć ją do 
development of rural green tourism, being integrated into the Rural Tourism Development Program of Ukraine, define the features and conditions for contracts in the field of rural green tourism, resolve issues related to the professional training of rural green tourism professionals. At the same time, the main task in formulating such a Program is to coordinate the efforts of the government, parliament, ministries, departments, other state authorities, as well as public organizations and business structures for more efficient development of rural green tourism in Ukraine.

Summarizing the existing practice, there are several areas of tourism services in the UTC:

- cognitive (acquaintance with cultural, historical, ethnographic, natural values of the territory);

- entertaining (fishing, hunting, gathering mushrooms, berries, medicinal herbs, boating);

- recreation (swimming in ponds, physical labor).

The offer for a tourist product in the UTC is divided into a primary one, realized directly by the producer of tourism services - farmstead, and a secondary one, when mediators are involved, who benefit from the resale of services (All about tourism, 2017).

The identification of strengths and weaknesses, opportunities and threats (Table 3) is also important for the development of tourism, as well as the basis for capacities of UTCs.

The development of tourism in the UTC does not require much expense, since it is based on the lifestyle and features of local residents. However, the legislation of Ukraine does not set requirements for the owners of estates for the organization of life and facilities for visitors. The development of rural green tourism is of great importance both to tourists and to the UTC, which will contribute to the socio-economic development of the area. Tourists are provided with active rest in the UTC, consumption of fresh food, communication with local people, learning about culture, customs and traditions, acquiring new skills, contact with nature and more. For territorial development, tourism makes it possible to obtain additional income, improve the infrastructure of the territory, preserve cultural heritage, and personal development of the local population (Table 4).

As already mentioned, the effective promotion of the national tourism product on the foreign market requires both organizational and partial financial support from the state, and the creation of a positive image of the country and its tourist facilities should become part of the overall strategy of tourism development in the UTC of Ukraine (Kostrytsya, 2006). Therefore, private-public partnership plays an important role here. The UTC that can provide privileges for receiving state grants to persons involved in the provision of tourist services. Rural green tourism is developed with the close cooperation of the interested rural population, who provide tourism services of the UTC. UTCs provide high quality tourist services and appropriate communal infrastructure (roads, parking lots, standardów UE, należy pilnie dostosować ukraińską ustawę o agroturystyce ekologicznej. Ustawa ta stałaby się wtedy podstawą rozwoju regionalnego agroturystyki ekologicznej zintegrowaną z programem rozwoju ukraińskiej agroturystyki, określałaby cechy i warunki umów dotyczących agroturystyki ekologicznej oraz rozwiązałaby kwestie związane ze szkoleniem zawodowym specjalistów agroturystyki ekologicznej. Jednocześnie głównym zadaniem przy formułowaniu takiego Programu jest koordynacja działań rządu, parlamentu, ministerstw, departamentów i innych organów państwowych, a także organizacji publicznych i struktur biznesowych w celu skuteczniejszego rozwoju agroturystyki ekologicznej na Ukrainie.

Podsumowując dotychczasowe praktyki, wyróżnia się kilka obszarów usług turystycznych w ramach ZWT:

- poznawczy (znajomość wartości kulturowej, historycznej, etnograficznej i naturalnej obszaru);

- rozrywkowy (wędkarstwo, polowania, zbieranie grzybów, jagód, ziół leczniczych, żeglowanie);

- rekreacja (pływanie w stawach, praca fizyczna).

Oferta produktu turystycznego w ZWT dzieli się na pierwotną, realizowaną bezpośrednio przez wytwórcę usług turystycznych - gospodarstwo, oraz wtórną, kiedy zaangażowani są pośrednicy, którzy korzystają z odsprzedaży usług (All about tourism/ Wszystko o turystyce, 2017)..

Wskazanie mocnych i słabych stron, możliwości i zagrożeń (Tabela 3) jest również ważne dla rozwoju turystyki oraz stanowi podstawę zdolności ZWT.

Rozwój turystyki w ZWT nie wymaga znacznych nakładów, ponieważ bazuje na stylu życia i możliwościach lokalnych mieszkańców. Ustawodawstwo ukraińskie nie określa jednak wymogów dla właścicieli obiektów co do organizacji pobytu i udogodnień dla gości. Rozwój agroturystyki ekologicznej ma ogromne znaczenie zarówno dla turystów, jak i ZWT, przyczyniając się do rozwoju społeczno-ekonomicznego obszaru. Turyści mogą w ZWT korzystać z aktywnego wypoczynku, świeżej żywności, mogą nawiązywać kontakty z miejscowymi, poznawać kulturę, zwyczaje i tradycje, nabywać nowe umiejętności, nawiązywać więź z przyrodą itd. Jeśli chodzi o rozwój lokalny, turystyka pozwala na uzyskanie dodatkowych dochodów, poprawę infrastruktury regionu, ochronę dziedzictwa kulturowego oraz rozwój indywidualny mieszkańców (Tabela 4).

Jak już wspomniano, skuteczna promocja krajowego produktu turystycznego na rynku zagranicznym wymaga wsparcia organizacyjnego i dofinansowania ze strony państwa, a tworzenie pozytywnego wizerunku kraju i jego atrakcji turystycznych powinno stać się elementem ogólnej strategii rozwoju turystyki w ZWT na Ukrainie (Kostrytsya, 2006). Dlatego partnerstwo publiczno-prywatne odgrywa tutaj istotną rolę. ZWT mogą uzyskiwać przywileje w postaci dotacji państwowych dla osób zaangażowanych w świadczenie usług turystycznych. Rozwój agroturystyki ekologicznej odbywa się w ścisłej współpracy z zainteresowanymi mieszkańcami wsi, którzy świadczą usługi turystyczne w ramach ZWT. ZWT zapewniają 
Table 3. SWOT-analysis of the development of tourism in the UTC of Ukraine

Tabela 3. Analiza SWOT rozwoju turystyki w ZWT na Ukrainie

\begin{tabular}{|c|c|}
\hline $\begin{array}{l}\text { Strengths of the UTC for the favorable development of tourism } \\
\text { are a clean and safe environment, beautiful landscape, rich } \\
\text { flora and fauna, the presence of rivers, mountains, lakes, } \\
\text { forests, a wealth of historical and cultural sites, low cost } \\
\text { of living and food, a large number of individual operators, } \\
\text { traditionally receiving guests, preserved rural traditions, } \\
\text { hospitality of the population./ } \\
\text { Mocne strony ZWT w kontekście pomyślnego rozwoju tury- } \\
\text { styki to czyste i bezpieczne środowisko, piękne krajobrazy, } \\
\text { bogata flora i fauna, występowanie rzek, gór, jezior, lasów, } \\
\text { bogactwo obiektów historycznych i kulturowych, niski koszt } \\
\text { utrzymania i wyżywienia, duża liczba indywidualnych opera- } \\
\text { torów, tradycyjne podejmowanie gości, życie zgodnie z trady- } \\
\text { cją, gościnność. }\end{array}$ & $\begin{array}{l}\text { Weaknesses of the UTC which can hinder the development } \\
\text { of tourism are poor quality of lodging facilities, problems } \\
\text { with water supply, lack of sufficient practical tourist } \\
\text { information about the region, the ignorance of owners of rural } \\
\text { estates of foreign languages, lack of seat reservation, poor } \\
\text { marking of tourist attractions and routes, underdeveloped } \\
\text { infrastructure./ } \\
\text { Do słabych stron ZWT, które mogą zakłócać rozwój turysty- } \\
\text { ki, należą niska jakość obiektów zakwaterowania, problemy } \\
\text { z dostawą wody, brak wystarczających informacji praktycz- } \\
\text { nych dla turystów na temat regionu, brak znajomości języ- } \\
\text { ków obcych ze strony właścicieli, brak możliwości rezerwacji } \\
\text { miejsc, niewystarczające oznaczenie atrakcji turystycznych } \\
\text { i ścieżek, wybrakowana infrastruktura. }\end{array}$ \\
\hline $\begin{array}{l}\text { Threats that will impede tourism development and } \\
\text { must be prevented are the emergence of an unclassified } \\
\text { accommodation base that will reduce the quality of services, } \\
\text { a significant unemployment rate creates the basis for } \\
\text { increased crime, deterring potential tourists, rivalry and lack } \\
\text { of coordination between different tourism organizations, } \\
\text { impedes the implementation of common strategic goals for } \\
\text { rural tourism development in the region, poor political image } \\
\text { does not support the activities of foreign investors, the lack of } \\
\text { political stability and the law „On Rural Tourism” hinder rural } \\
\text { recreation./ } \\
\text { Zagrożenia, które zakłócają rozwój turystyki i którym należy } \\
\text { zapobiegać, to pojawienie się niesklasyfikowanych obiektów } \\
\text { w ramach bazy noclegowej, co doprowadzi do obniżenia jako- } \\
\text { ści usług; znaczny wskaźnik bezrobocia tworzy warunki do } \\
\text { zwiększonej przestępczości, odstraszając potencjalnych tury- } \\
\text { stów, rywalizacja i brak koordynacji między poszczególnymi } \\
\text { organizacjami turystycznymi, utrudnione wdrażanie wspól- } \\
\text { nych celów strategicznych rozwoju agroturystyki w regionie, } \\
\text { niekorzystny wizerunek polityczny, brak wsparcia dla inwe- } \\
\text { storów zagranicznych, brak stabilności politycznej i przepisy } \\
\text { ustawy o agroturystyce hamują rozwój rekreacji wiejskiej. }\end{array}$ & $\begin{array}{l}\text { Potential opportunities and benefits of tourism development } \\
\text { in the UTC are the following: development of eco-tourism } \\
\text { in which households will act as a base for overnight stays; } \\
\text { possibility to regulate tourist flows and economic activity } \\
\text { by economic methods; creation of a favorable information } \\
\text { environment for both owners and tourists through } \\
\text { integration with the information and analytical center for } \\
\text { rural green tourism development; the possibility of mutually } \\
\text { beneficial cooperation with the agricultural sector through } \\
\text { the introduction of innovative forms of rural green tourism./ } \\
\text { Potencjalne szanse i korzyści wynikające z rozwoju turystyki } \\
\text { w ZWT są następujące: rozwój ekoturystyki, w ramach której } \\
\text { gospodarstwa domowe będą stanowić podstawę bazy nocle- } \\
\text { gowej; możliwość regulacji przepływów turystów i działal- } \\
\text { ności gospodarczej metodami gospodarczymi; stworzenie } \\
\text { sprzyjającego środowiska informacyjnego dla właścicieli } \\
\text { i turystów poprzez integrację z centrum informacyjno-anali- } \\
\text { tycznym ds. rozwoju agroturystyki ekologicznej; możliwość } \\
\text { obopólnie korzystnej współpracy z sektorem rolnym dzięki } \\
\text { wprowadzeniu innowacyjnych form turystyki ekologicznej. }\end{array}$ \\
\hline
\end{tabular}
ustawy o agroturystyce hamują rozwój rekreacji wiejskiej.

Source: Own elaboration.

Źródło: Opracowanie własne.

centralized water supply and sewerage, telephony, security, etc.), offering a wide range of private estates, shops, sports and recreational facilities and tourist services.

Another part of the touristic offer is living conditions. Living conditions must guarantee the possibility of a comfortable overnight stay, personal hygiene and good nutrition. Therefore, the population should be guided by the categorization of rural housing of the Ukrainian Union for the Promotion of Rural Green Tourism. Assigning a category of housing provided for the use of holidaymakers entitles the landlord to report the appropriate quality of living conditions in the union's advertising facilities, which will increase the touristic demand and income of the landlord (Ukrainian hospitable estates, 2019).

The development of tourism in the UTC encourages improvement of rural estates, streets, villages as a whole; stimulates the development of social infrastructure. Of course, at first, the reception and service of vacationers is based on existing housing stock using local recreational and infrastructural resources. But with some income wysokiej jakości usługi turystyczne i odpowiednią infrastrukture komunalną (drogi, parkingi, sieć wodociągów i odprowadzania ścieków, sieć telefoniczna, zapewnienie bezpieczeństwa itd.), oferując szeroki zakres obiektów prywatnych, sklepów, ośrodków sportowo-rekreacyjnych i usług turystycznych.

Kolejnym elementem oferty turystycznej są warunki pobytu. Muszą one gwarantować wygodny nocleg, dostęp do łazienki i dobrej jakości wyżywienie. Należy przestrzegać kategoryzacji wiejskich obiektów turystycznych stworzonej przez Ukraińską Unię Promocji Agroturystyki Ekologicznej. Przypisanie kategorii obiektu na potrzeby wczasowiczów umożliwia właścicielowi zgłoszenie stosownej jakości oferowanych usług, która zostanie ujęta w materiałach prezentowanych w materiałach promocyjnych organizacji, co pozwoli na zwiększenie zainteresowania usługami danego obiektu i dochodu właściciela (Ukrainian hospitable estates, 2019).

Rozwój turystyki w ZWT stymuluje rozwój obiektów na terenach wiejskich i ulic oraz wpływa na ogólny rozwój wsi, a także infrastruktury społecznej. Oczywiście początkowo przyjmowanie i obsługa wczasowiczów odbywają się w oparciu o istniejącą bazę 
Table 4. A set of tasks for the UTC to support the development of rural green tourism

Tabela 4. Zbiór zadań ZWT mających na celu wspieranie rozwoju agroturystyki ekologicznej

\begin{tabular}{|c|c|}
\hline $\begin{array}{l}\text { Characteristics of the welfare of the } \\
\text { population/ } \\
\text { Cechy dobrobytu ludności }\end{array}$ & $\begin{array}{l}\text { Tasks of territorial communities/ } \\
\text { Zadania społeczności lokalnych }\end{array}$ \\
\hline $\begin{array}{l}\text { Improving the living standards of the } \\
\text { population of the territory/ } \\
\text { Poprawa standardów życia ludności danego } \\
\text { obszaru }\end{array}$ & $\begin{array}{l}\text { State support for improving the level of development of the territory as a sphere } \\
\text { of life, activities of the inhabitants, delineation of the policy on support of } \\
\text { agriculture and rural development/ } \\
\text { Wsparcie państwa w celu podniesienia poziomu rozwoju obszaru jako elementu } \\
\text { życia mieszkańców, aktywizacja mieszkańców, wyznaczenie polityki wsparcia } \\
\text { rolnictwa i rozwoju obszarów wiejskich }\end{array}$ \\
\hline $\begin{array}{l}\text { Employment of the population/ } \\
\text { Zatrudnienie }\end{array}$ & $\begin{array}{l}\text { Encouraging rural employment outside the agricultural sector, including the } \\
\text { development of agrarian business, rural tourism, folk crafts, service businesses, } \\
\text { gathering and processing of wild berries and mushrooms, medicinal raw } \\
\text { materials, etc./ } \\
\text { Wspieranie zatrudnienia na obszarach wiejskich poza sektorem rolnym, } \\
\text { z uwzględnieniem rozwoju działalności rolnej, turystyki rolnej, rękodzieła } \\
\text { ludowego, działalności usługowej, zbierania i przetwarzania jagód i grzybów, } \\
\text { surowców leczniczych itd. }\end{array}$ \\
\hline $\begin{array}{l}\text { Development of rural social infrastructure/ } \\
\text { Rozwój wiejskiej infrastruktury społecznej }\end{array}$ & $\begin{array}{l}\text { Priority development of rural social sphere and infrastructure (first of all roads, } \\
\text { telecommunications and other media, utilities, education and health)/ } \\
\text { Priorytetowy rozwój wiejskiej sfery i infrastruktury społecznej (przede } \\
\text { wszystkim drogi, sieć telekomunikacyjna i pozostałe media, placówki } \\
\text { edukacyjne i opieki zdrowotnej) }\end{array}$ \\
\hline $\begin{array}{l}\text { Social development of the village/ } \\
\text { Rozwój społeczny wsi }\end{array}$ & $\begin{array}{l}\text { Creating conditions for rural social development, sustainable motivation for } \\
\text { social responsibility of businesses in the agrarian sector, related sectors of } \\
\text { production and services/ } \\
\text { Tworzenie warunków dla rozwoju społecznego wsi, stała motywacja dla działań } \\
\text { z zakresu społecznej odpowiedzialności biznesu w sektorze rolnym, powiązane } \\
\text { sektory produkcyjne i usługowe }\end{array}$ \\
\hline $\begin{array}{l}\text { Formation of attractive image of rural } \\
\text { area/ } \\
\text { Tworzenie atrakcyjnego wizerunku } \\
\text { obszaru wiejskiego }\end{array}$ & $\begin{array}{l}\text { Increasing the level of attractiveness of living in rural areas, implementing the } \\
\text { program of state support for young workers in rural settlements/ } \\
\text { Zwiększanie poziomu atrakcyjności obszarów wiejskich jako miejsca do życia, } \\
\text { wdrażanie programu wsparcia państwa dla młodych pracowników na wsi }\end{array}$ \\
\hline $\begin{array}{l}\text { Increase in revenue/ } \\
\text { Zwiększenie przychodów }\end{array}$ & $\begin{array}{l}\text { Creating a level playing field to support farmers, regardless of their type, type, } \\
\text { size, ownership and management/ } \\
\text { Tworzenie równych szans dla rolników, niezależnie od rodzaju, wielkości, formy } \\
\text { własności i sposobu zarządzania gospodarstwem }\end{array}$ \\
\hline
\end{tabular}

Source: Ivashyna, 2017.

Źródło: Ivashyna, 2017.

from this activity, it is possible to start investing in improving the municipal housing, streets; united efforts are being made to improve the service industry. This is also a significant contribution to the development of UTC.

\section{Conclusions}

Therefore, rural green tourism in the UTC of Ukraine is gaining popularity every year both in the world and in the country. It enables, on the one hand, the activation of low-income part of the population, which can count on relatively cheap rest, and on the other hand, facilitates the development of farms providing rural green tourism services, the creation of new businesses that will enable UTC residents to find jobs. At the same time, it will reduce the migration of able-bodied population outside the country, as well as allow attracting both domestic and foreign investments, as well as implement new projects, which in turn will generate mieszkaniową z wykorzystaniem lokalnych zasobów rekreacyjnych i infrastrukturalnych. Po uzyskaniu pewnego poziomu dochodów z tej działalności można rozpocząć inwestycje $\mathrm{w}$ poprawę stanu obiektów komunalnych i ulic. Prowadzone sa również wspólne działania na rzecz ulepszeń w branży usługowej. Mają one również znaczny wpływ na rozwój ZWT.

\section{Podsumowanie}

Agroturystyka ekologiczna w ukraińskich ZWT z każdym rokiem zyskuje na popularności zarówno wśród turystów międzynarodowych, jak i krajowych. $\mathrm{Z}$ jednej strony umożliwia ona aktywizację najmniej zarabiającej części populacji, która może liczyć na stosunkowo niedrogi wypoczynek, a z drugiej strony wspiera rozwój gospodarstw świadczących ekologiczne usługi agroturystyczne i powstawanie nowych przedsiębiorstw, w których mieszkańcy ZWT mogą znaleźć zatrudnienie. Jednocześnie ten rodzaj turystyki pozwoli na ograniczenie migracji zagranicznych zdolnej do pracy ludności oraz przyciągnie inwestycje krajowe i zagraniczne, a także umożliwi realizację 
significant additional revenues to the UTC budget and strengthen their capacity.

When developing tourism, the community has to consider four main points:

1. Tourist resources.

2. Opportunity to get to tourist resources.

3. Availability of infrastructure.

4. Availability of people for management, promotion, marketing in the field of tourism.

The main directions for the development of rural green tourism should be to strike a balance between the socio-economic needs of society and the conservation of the natural environment. In general, touristic UTC can gain competitive advantages in the following ways: adaptation to external conditions, mobilization of internal reserves, integration with other areas or the environment.

The strategy for developing green tourism in UTC should take into account the following aspects: adaptation of the legal framework to the standards adopted in Europe; organizing promotional activities to improve the quality of the tourism product based on European norms and environmental parameters; formation of the tourist image of UTC by highlighting the specific specialized features of the rural green tourism product.

It is necessary to proceed from logic of location, influence of tourist resource and, if necessary, to combine efforts for its development with neighbors. Therefore, to strengthen the capacity of the UTC, rural green tourism is one of the key priorities for overcoming depression and enhancing the socioeconomic development of the UTC territories.

\section{References/ Literatura:}

1. Kravchuk, A.O. (2014). Rural tourism as a strategic direction for diversification of operational activity of subjects of the agrarian sector of Odessa region. Economic analysis, 3(18), 45-51.

2. Popadynets, N.M. (2018). Impact of trade on the development of a tourism cluster in a region. Socio-economic problems of the modern period of Ukraine, 4(132), 23-28.

3. Cherniava, G.L. (2012). Theoretical approaches to defining the concept, essence of alternatives to the development of rural green tourism. Culture of the Black Sea peoples, 227, 85-88.

4. Shulgina, L.M., Zinchenko, A.I., Krahmaliova, N.A. (2014). Marketing activities of enterprises in the market of green tourism services. Kyiv: Kyiv National University of Technology and Design.

5. Korchinska, 0.0. (2015). Development of entrepreneurship in the field of rural green tourism. Dissertation for the Candidate Degree in Economics. Lviv: Ivan Franko National University of Lviv.

6. Kudla, N.Ye. (2015). Rural tourism: the basics of entrepreneurship and hospitality. Kyiv: Center for Educational Literature.

7. Zinko, Yu.V., Gorishevsky, P.A., Vasilyev, V.P., Blagodyr, S.F., Ivanyk, M.B. (2011). Using Italian legislative experience to develop bills in the rural tourism of Ukraine. Geography and Tourism, 16, 34-39.

8. Rossokha, V., Plotnikova, M. (2018). Development of Rural Regions of Ukraine in Conditions Of Decentralization of Management: State, Problems, Perspectives. The Economic Discourse, 4, 41-53.

9. All about tourism. (2015). European experience in organizing rural green tourism. Tourist Library. http://tourlib.net/ statti_ukr/siltur2.htm

10. EuroGites (2019). About EuroGites. https://www.eurogites.org/about/

11. Ivanyshyn, V.V., Dudzyak, O.A. (2019). Application of the experience of rural development of European countries and the USA in Ukraine. Collection of scientific works of Podilsky State Agrarian and Technical University, 24(3), 5-10.

12. Ukrainian hospitable estates (2019). History. https://www.greentour.com.ua/en/

13. State Statistics Service of Ukraine. (2019). Collective Placement - 2018. https://ukrstat.org/uk/operativ/operativ2019/ tyr/kol_zas_ukr/arch_kol_zas_ukr.htm

14. All about tourism.(2017). Prospects for the development of rural green tourism in Ukraine. Tourist Library. http://tourlib. net/statti_ukr/siltur7.htm

15. Kostrytsya, M. M. (2006). Rural tourism: theory, methodology, practice (ethnohistorical tourist cluster "Drevlyany land". Zhytomyr: ZhDTU.

16. Ivashyna, L. (2017). Role of united local communities in rural green tourism development. Public Administration and Local Government, 3(34),143-148. 